\title{
Clinician-related factors behind the decision to extract an asymptomatic lower third molar. A cross-sectional study based on Spanish and Portuguese dentists
}

\author{
Daniela Alves-Pereira ${ }^{1}$, David Pereira-Silva ${ }^{2}$, Rui Figueiredo ${ }^{3}$, Cosme Gay-Escoda ${ }^{4}$, Eduard Valmaseda- \\ Castellón ${ }^{5}$
}

${ }^{1}$ DDS, MS, Master of Oral Surgery and Implantology. Assistent Professor of Oral Surgery, School of Medicine, University of Coimbra, Portugal

${ }^{2}$ DDS, MS, Master of Orthodontics. Clinical practice in Orthodontics, Coimbra, Portugal

${ }^{3}$ DDS, MS, PhD, Master of Oral Surgery and Implantology. Associate Lecturer in Oral Surgery, Lecturer on the Master of Oral Surgery and Implantology degree course. School of Dentistry, University of Barcelona. Researcher at the Idibell Institute. Barcelona, Spain

${ }^{4}$ MD, DDS, MS, EBOS, OMFS, PhD, Chairman and Professor of Oral and Maxillofacial Surgery, School of Dentistry, University of Barcelona. Director of Master's Degree Program in Oral Surgery and Implantology (EHFRE International University/ FUCSO). Coordinator/Researcher of the Bellvitge Biomedical Research Institute (Idibell). Head of Oral Surgery, Implantology and Maxillofacial Surgery Department of the Teknon Medical Center, Barcelona, Spain

${ }^{5}$ DDS, MS, PhD, EBOS. Tenured lecturer in Oral Surgery, Director of the Master of Oral Surgery and Implantology. School of Dentistry degree course, University of Barcelona. Researcher at the Idibell Institute. Barcelona, Spain

Correspondence:

Faculty of Dentistry. Campus de Bellvitge

University of Barcelona

C/ Feixa Llarga, s/n

Pavelló Govern, $2^{a}$ planta, Despatx 2.10

08907 L'Hospitalet de Llobregat

Barcelona, Spain

rui@ruibf.com

\begin{abstract}
Alves-Pereira D, Pereira-Silva D, Figueiredo R, Gay-Escoda C, Valmaseda-Castellón E. Clinician-related factors behind the decision to extract an asymptomatic lower third molar. A cross-sectional study based on Spanish and Portuguese dentists. Med Oral Patol Oral Cir Bucal. 2017 Sep 1;22 (5):e609-15.

http://www.medicinaoral.com/medoralfree01/v22i5/medoralv22i5p609.pdf
\end{abstract}

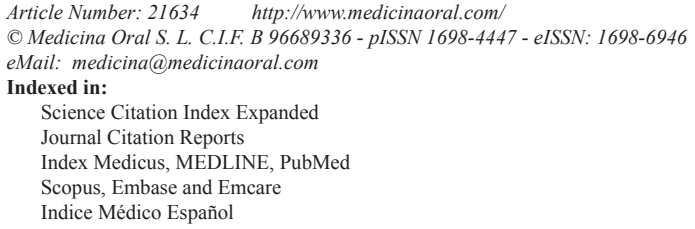

\begin{abstract}
Background: Scientific literature estimates that around 18 to $40 \%$ of asymptomatic third molars are extracted. The aims of the present study were to determine the indications for extraction of asymptomatic lower third molars in a sample of Spanish and Portuguese dentists, and to relate these indications to the clinicians' training and professional experience.

Material and Methods: A survey consisting of 15 cases of asymptomatic lower third molars was emailed to Portuguese and Spanish dentists. The clinicians were asked to assess the level of difficulty of the extractions and to make a reasoned recommendation based on the panoramic radiographs, gender and age of the patients.

Results: 381 clinicians filled in the questionnaires. Most of the professionals had over 13 years of clinical experience. The number of Spanish clinicians with postgraduate degrees in Oral Surgery was significantly higher. On average, $42 \%$ of respondents recommended extraction of asymptomatic third molars. The indication for extraction was significantly higher among Portuguese dentists. Clinical experience was negatively correlated with the perceived
\end{abstract}


extraction difficulty $(p<0.05)$. The main reason given for extracting was the prevention of pericoronitis, whereas that for not extracting was the absence of a clear indication and the risk of injuring the inferior alveolar nerve.

Conclusions: The Portuguese dentists were more in favour of removing asymptomatic lower third molars than the Spanish dentists, although the latter had a higher proportion of professionals with postgraduate studies in Oral Surgery.

Key words: Third molar, Tooth extraction, Oral Surgery, Indication, Prophylactic removal.

\section{Introduction}

Approximately two-thirds of the world population has at least one third molar (3M) by the age of 20 years (1). In Europe, this is the case in approximately $73 \%$ of subjects (2). Extraction of these teeth is the most common surgical procedure in dentistry: it is estimated that around 1 million extractions are performed annually in the United Kingdom and 5 million in the USA (3). In the year 2000, the clinical guidelines of the National Institute for Health and Care Excellence (NICE) in the United Kingdom recommended specific indications for this surgery, at a time when prophylactic extraction was considered unadvisable (5)

However, on looking carefully at the impact of these practice guidelines, although $3 \mathrm{M}$ extractions decreased in the years following their introduction the current figures are again similar to those existing before the guidelines were published (4,5). Furthermore, in 2007 the American Association of Oral and Maxillofacial Surgeons (AAOMS) revised the core clinical aspects relating to $3 \mathrm{Ms}$ and their extraction. The working group of the AAOMS estimated that $85 \%$ of asymptomatic $3 \mathrm{Ms}$ were extracted in later stages. Such fragmented criteria result in dentists making different decisions as to whether or not to extract an asymptomatic $3 \mathrm{M}$, probably due to different risk and benefit assessments.

Reports in the scientific literature indicate that around $18 \%$ to $40 \%$ of $3 \mathrm{Ms}$ are extracted without any pathological sign. The decision is based on the need to minimise the future risk of tooth pathology and to reduce age-related surgical morbidity (6). Although some publications compare extraction indications between clinicians, there is very little information about the factors (related either to the patient or the dentist) that influence the decision to extract an asymptomatic $3 \mathrm{M}(6-11)$.

The objectives of the present study were to look into the indications for extracting asymptomatic lower $3 \mathrm{Ms}$ in a sample of Spanish and Portuguese dentists, using a survey, and to link such indications to the clinicians' training and expertise.

\section{Material and Methods}

A request to participate in a survey consisting of 15 clinical cases was sent by email to dentists in Spain and Portugal. The questionnaire was available at a survey server (http://www.surveygizmo.com) and could be filled on-line.
In Spain, the request was made through professional associations of dentists in the different regions of the country. In Portugal, it was managed through Box4 ${ }^{\circledR}$, a private company dedicated to medical and dental information, which has a mailing list of all the dentists in the country. The questionnaire was first tested by a group of 6 dentists to ensure that the information in the survey was accurate, there were no misunderstandings and the results were recorded correctly. The surveys were completed during a 6-month period, between July 4, 2013 and January 23, 2014. This study was not submitted to an Ethics Committee since it was based on an anonymous survey made to dentists and the patients' used in this study were fictitious.

First, each dentist had to fill in personal, demographic and professional information. A clinical summary of 15 clinical cases of young healthy patients with 29 asymptomatic $3 \mathrm{Ms}$ was then shown, including panoramic radiographs and the age and gender of the patient. The cases were presented in random order to each respondent. The $3 \mathrm{Ms}$ represented a broad spectrum of asymptomatic third molars (Table 1). The respondent was asked to make a recommendation for each case (whether or not to extract) and to select a reason for that decision from a closed list of options. The clinicians also had to rate the extraction difficulty of each lower $3 \mathrm{M}$ on a Likert scale of 1-10.

The results were exported to a Microsoft Office $\AA$ XML $\AA$ spreadsheet (Microsoft Corp., Redmond, Washington, USA), accidentally duplicated replies were eliminated and the results were analysed using IBM SPSS ${ }^{\circledR} 22.0$ software (IBM Corp., New York, USA). Chi-square tests (categorical variables), Student's t-tests and Pearson's correlation for scale variables were used. The level of significance was set at $p<0.05$.

\section{Results}

Three hundred and ninety-six (396) clinicians completed the online questionnaire. The Spanish and Portuguese dentists were divided into two subgroups according to their country of residence (regardless of their nationality). There were 230 dentists working in Portugal, 151 in Spain and 15 in other countries. The latter were discarded because they were considered a small and heterogeneous group. Of the 381 respondents included in the study, 209 were female and 172 male.

Most of the dentists had over 13 years of clinical expe- 
Table 1: Description of age, gender (M: Male; F: Female) and radiographical landmarks (position and inclination of $3 \mathrm{M}$ according to the Winter and Pell and Gregory classifications, degree of soft tissue coverage and relationship with the mandibular canal).

\begin{tabular}{|c|c|c|c|c|c|c|}
\hline Case & Gender & Age & Tooth & $\begin{array}{l}\text { Pell \& Gregory } \\
\text { Classification }\end{array}$ & $\begin{array}{c}\text { Winter } \\
\text { Classification }\end{array}$ & $\begin{array}{l}\text { Radiographic signs of } \\
\text { increased risk of inferior } \\
\text { alveolar nerve injury }\end{array}$ \\
\hline 1 & $\mathrm{~F}$ & 36 & $\begin{array}{l}48 \\
38\end{array}$ & $\begin{array}{l}\text { IIIB } \\
\text { IIB }\end{array}$ & $\begin{array}{c}\text { Vertical } \\
\text { Distoangular }\end{array}$ & $\begin{array}{c}\text { Deflection of the root } \\
\text { Mandibular duct blockage }\end{array}$ \\
\hline 2 & M & 22 & $\begin{array}{l}48 \\
38\end{array}$ & $\begin{array}{l}\text { IIIC } \\
\text { IIIC }\end{array}$ & $\begin{array}{l}\text { Mesioangular } \\
\text { Mesioangular }\end{array}$ & $\begin{array}{c}\text { Darkening of the root } \\
\text { Mandibular duct blockage }\end{array}$ \\
\hline 3 & M & 32 & $\begin{array}{l}48 \\
38\end{array}$ & $\begin{array}{l}\text { IIIA } \\
\text { IIIB }\end{array}$ & $\begin{array}{l}\text { Mesioangular } \\
\text { Distoangular }\end{array}$ & - \\
\hline 4 & $M$ & 33 & $\begin{array}{l}48 \\
38\end{array}$ & $\begin{array}{l}\text { IIB } \\
\text { IIA }\end{array}$ & $\begin{array}{l}\text { Distoangular } \\
\text { Vertical }\end{array}$ & $\begin{array}{l}- \\
-\end{array}$ \\
\hline 5 & $\mathrm{~F}$ & 28 & $\begin{array}{l}48 \\
38\end{array}$ & $\begin{array}{l}\text { IIIB } \\
\text { IIIB }\end{array}$ & $\begin{array}{l}\text { Distoangular } \\
\text { Vertical }\end{array}$ & $\begin{array}{l}- \\
-\end{array}$ \\
\hline 6 & $\mathrm{~F}$ & 37 & 48 & IIIA & Horizontal & - \\
\hline 7 & M & 37 & $\begin{array}{l}48 \\
38\end{array}$ & $\begin{array}{l}\text { IA } \\
\text { IIB }\end{array}$ & $\begin{array}{c}\text { Vertical } \\
\text { Horizontal }\end{array}$ & Mandibular duct blockage \\
\hline 8 & $F$ & 26 & $\begin{array}{l}48 \\
38\end{array}$ & $\begin{array}{l}\text { IIA } \\
\text { IIA }\end{array}$ & $\begin{array}{l}\text { Distoangular } \\
\text { Mesioangular }\end{array}$ & Mandibular duct blockage \\
\hline 9 & $\mathrm{M}$ & 25 & $\begin{array}{l}48 \\
38\end{array}$ & $\begin{array}{l}\text { IIIB } \\
\text { IIIB }\end{array}$ & $\begin{array}{l}\text { Mesioangular } \\
\text { Mesioangular }\end{array}$ & $\begin{array}{l}\text { Deflection of the root } \\
\text { Darkening of the root }\end{array}$ \\
\hline 10 & $\mathrm{~F}$ & 24 & $\begin{array}{l}48 \\
38\end{array}$ & $\begin{array}{l}\text { IA } \\
\text { IA }\end{array}$ & $\begin{array}{l}\text { Mesioangular } \\
\text { Mesioangular }\end{array}$ & $\begin{array}{l}- \\
-\end{array}$ \\
\hline 11 & $\mathrm{~F}$ & 16 & $\begin{array}{l}48 \\
38\end{array}$ & $\begin{array}{l}\text { IIB } \\
\text { IIIB }\end{array}$ & $\begin{array}{c}\text { Mesioangular } \\
\text { Vertical }\end{array}$ & $\begin{array}{l}\text { Mandibular duct blockage } \\
\text { Mandibular duct blockage }\end{array}$ \\
\hline 12 & $\mathrm{M}$ & 19 & $\begin{array}{l}48 \\
38\end{array}$ & $\begin{array}{l}\text { IIIC } \\
\text { IIA }\end{array}$ & $\begin{array}{c}\text { Horizontal } \\
\text { Vertical }\end{array}$ & $\begin{array}{l}\text { Deflection of the root } \\
\text { Deflection of the root }\end{array}$ \\
\hline 13 & M & 21 & $\begin{array}{l}48 \\
38\end{array}$ & $\begin{array}{l}\text { IIB } \\
\text { IIIA }\end{array}$ & Distoangular & $\begin{array}{l}\text { Mandibular duct blockage } \\
\text { Mandibular duct blockage }\end{array}$ \\
\hline 14 & $\mathrm{~F}$ & 34 & $\begin{array}{l}48 \\
38\end{array}$ & $\begin{array}{l}\text { IA } \\
\text { IIA }\end{array}$ & $\begin{array}{l}\text { Vertical } \\
\text { Vertical }\end{array}$ & $\begin{array}{l}- \\
-\end{array}$ \\
\hline 15 & $F$ & 25 & $\begin{array}{l}48 \\
38\end{array}$ & $\begin{array}{l}\text { IIIB } \\
\text { IIB }\end{array}$ & $\begin{array}{l}\text { Vertical } \\
\text { Vertical }\end{array}$ & $\begin{array}{c}\text { Darkening of the root } \\
\text { Mandibular duct blockage }\end{array}$ \\
\hline
\end{tabular}

rience. The median graduation year was similar in the Spanish and Portuguese dentists (2003).

In this sample, $12.4 \%$ of the respondents had a teaching position at a University. This figure was significantly higher $(p=0.045)$ among Portuguese dentists $(14.8 \%$ vs. $7.9 \%)$.

Most (74.8\%) were general practitioners but many had received training in some specific field. Indeed, $45.1 \%$ of the general dentists practised Oral Surgery, 28.1\% Periodontology and 26\% Orthodontics. The proportion of Orthodontics postgraduates was $29.1 \%$, clinicians with a postgraduate degree in Oral Surgery were 28.1\% and Periodontics postgraduates were $13.4 \%$ of the sample (Fig. 1).
In Spain, the proportion of dentists with a postgraduate diploma in Oral Surgery who completed the survey was significantly higher than in Portugal ( $41.7 \%$ vs. $19.1 \% . p=2-10-6$ ), which reflects that in Spain more respondents practised Oral Surgery $(53.6 \%$ vs. $39.6 \%)$ $(p=0.007)$.

The estimated difficulty of $3 \mathrm{M}$ surgery was negatively correlated with experience: the most recent graduates rated the cases as more difficult. On the other hand, Portuguese dentists found lower $3 \mathrm{Ms}$ easier to extract than their Spanish colleagues $(p<0.05)$.

On average, the dentists recommended extraction of $42 \%$ of the asymptomatic third 3Ms (38.3\% in Spain and $44.5 \%$ in Portugal). Fewer Spanish than Portuguese cli- 


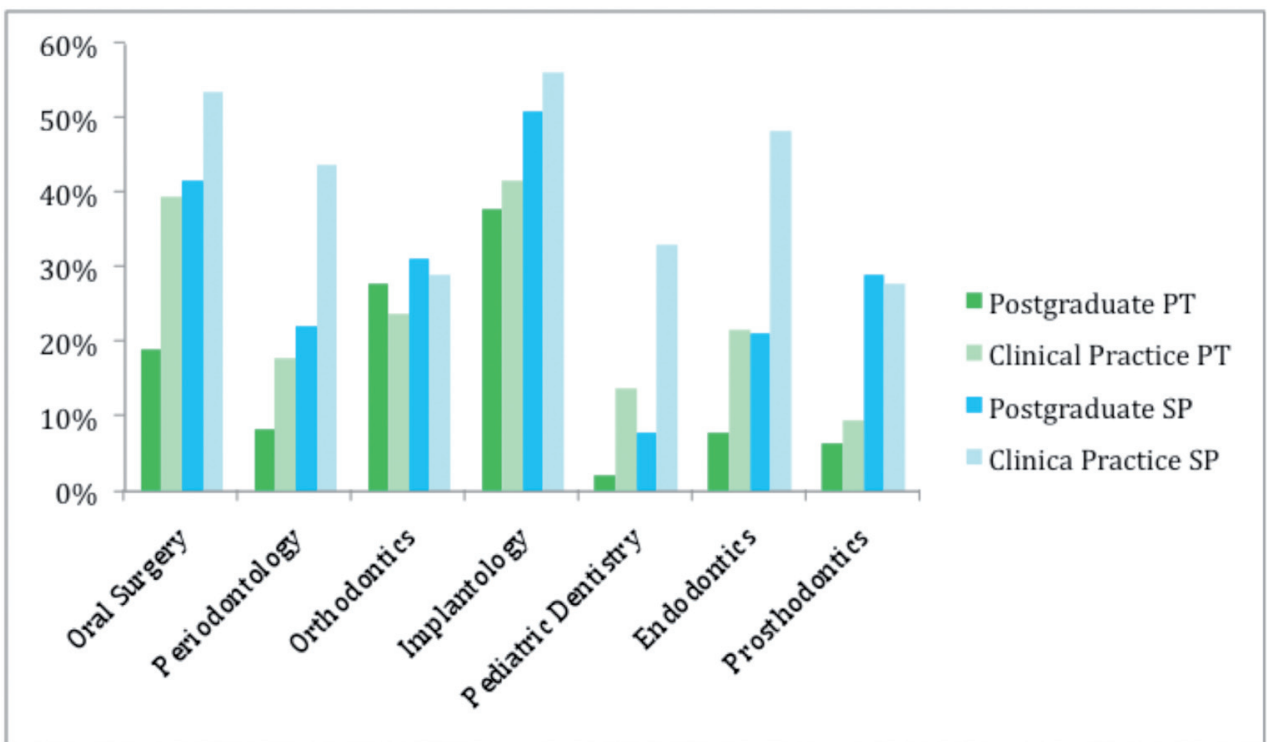

Fig. 1: Distribution of the Portuguese (PT) and Spanish (SP) respondents according to their daily clinical practice and postgraduate education.

nicians recommended extractions in 23 of the $293 \mathrm{Ms}$, although the difference was statistically significant in only 8 out of the $293 \mathrm{Ms}(p<0.05)$.

None of the clinicians considered the probability of cyst formation as an indicator for asymptomatic lower $3 \mathrm{M}$ removal. In contrast, the risk of pericoronitis was the main reason provided for lower $3 \mathrm{M}$ extraction (Table 2).

More than $30 \%$ of all the clinicians found extraction unnecessary because they did not foresee complications in the short to medium term. After this, the most frequent reason for not recommending the removal of an asymptomatic $3 \mathrm{M}$ was the tooth's proximity to the lower alveolar nerve and the risk of nerve injury. Spanish clinicians expressed this concern more often than Portuguese dentists (Table 3).

When the decision not to extract a third molar was taken, patient age was the reason least often given by both Spanish and Portuguese clinicians, except in one case of a 16-year old patient with two germs. In this case, $18 \%$ of respondents mentioned age as a reason for not recommending extraction. Of all the Portuguese respondents, $20 \%$ assumed that there was apparently no need to extract tooth germs and around 30\% stated that these teeth could still erupt $(p<0.05)$. About $16 \%$ of Spanish respondents believed that the tooth germs could still erupt.

\section{Discussion}

Although there appears to be a positive correlation between the decision to remove a third molar and the risk of developing a disease (6), the dentist's ability to predict such a risk is very limited. The present study showed that Portuguese clinicians tend more towards extraction. This may be because Portuguese dentists considered the $293 \mathrm{M}$ extraction simpler than did their Spanish colleagues. There appears to be a correlation between the $3 \mathrm{M}$ extraction difficulty, its position in relation to the ascending ramus of the mandible (2) and

Table 2: Core indications mentioned by the Portuguese and the Spanish clinicians for extracting asymptomatic lower $3 \mathrm{Ms}$.

\begin{tabular}{|l|c|c|c|c|}
\hline Indication & Total (\%) & Spain (\%) & Portugal (\%) & Difference $(\boldsymbol{p}<\mathbf{0 . 0 5})$ \\
\hline Pericoronaritis & 21.0 & 19.4 & 21.7 & $8 / 29$ cases \\
\hline Distal caries in the 2M & 13.8 & 11.3 & 13.9 & $1 / 29$ cases \\
\hline Lack of function & 12.0 & 11.0 & 12.6 & $2 / 29$ cases \\
\hline Resorption of the 2M & 11.5 & 9.4 & 13.4 & $5 / 29$ cases \\
\hline Periodontal injury of the 2M & 10.2 & 10.1 & 10.2 & - \\
\hline Caries in the 3M & 7.0 & 6.0 & 7.7 & $1 / 29$ cases \\
\hline Lower dental crowding & 5.2 & 5.0 & 5.8 & - \\
\hline Cyst & 0 & 0 & 0 & - \\
\hline
\end{tabular}


Table 3: Core reasons mentioned by the Portuguese and Spanish clinicians for not extracting asymptomatic lower $3 \mathrm{Ms}$.

\begin{tabular}{|l|c|c|c|c|}
\hline Contraindication & Total (\%) & Spain $\mathbf{( \% )}$ & Portugal $(\mathbf{\%})$ & Difference $(\boldsymbol{p}<\mathbf{0 . 0 5})$ \\
\hline Unnecessary surgery & 32.8 & 31.8 & 33.5 & $8 / 29$ cases \\
\hline Alveolar nerve injury & 12.2 & 16.0 & 9.7 & $12 / 29$ cases \\
\hline Could erupt & 5.4 & 4.5 & 6.0 & $2 / 29$ cases \\
\hline Aggressive surgery & 3.9 & 4.3 & 3.7 & $5 / 29$ cases \\
\hline Age of the patient & 3.3 & 3.1 & 3.4 & - \\
\hline 2M injury & 1.6 & 2.1 & 1.2 & - \\
\hline Mandibular fracture & 1.0 & 0.7 & 1.3 & - \\
\hline
\end{tabular}

patient age (11). Other factors like the surgeon's experience also play a crucial role. Therefore, clinicians are advised to have excellent technical and anatomical skills before performing surgical procedures (12). Knutsson et al. (9) highlighted that general dental practitioners who comprised the vast majority of our sample (74.8\%) - had limited access to scientific papers, while postgraduates were apparently more familiar with both international literature and the analytical tools needed to interpret and analyse outcomes. In the sample from Portugal, a higher proportion of professionals with teaching activities replied to the survey, but most of them were not experts in Oral Surgery. In contrast, Berrocal et al. (13) analysed students' perceptions of the Oral Surgery curricula taught in Spanish public Universities and concluded that most undergraduates found it to be adequate, except for the most complex surgical procedures. To our knowledge, there are no similar courses in Portugal.

In this study, the proportion of dentists with oral surgery postgraduate degrees was much higher in Spain. This marked difference is not due to a bias in survey distribution, but to general dentists apparently not responding to the questionnaire to the same extent as in Portugal. It must also be mentioned that in Spain and Portugal at the time of the survey there was no official specialisation in oral surgery, and the content of the respondents' postgraduate education could be very different. The imbalance between dentists with and without postgraduate diplomas in oral surgery could explain the observed differences between Spanish and Portuguese dentists better than the country in which they practiced (10). The more conservative attitude might be due to a better knowledge of the practice guidelines that do not recommend prophylactic removal of $3 \mathrm{M}$. In addition, practising oral surgery on a daily basis seems to help maintain surgical skills (12). These variations between clinicians from two different countries had already been seen in another comparative study involving the UK and Hong Kong (8).

The present study also proved that experience enhanced confidence (the difficulty was rated lower), probably due to increased surgical skills arising from years of professional activity (14).

Although the clinicians in this study did not recommend third molar removal to prevent cyst formation, the scientific literature shows that the prevalence of cyst and tumour development around lower $3 \mathrm{Ms}$ ranges between $2 \%$ and $6.2 \%$ in the long term (15). Although the risk factors for cystic or tumour development are unknown, pericoronal radiolucencies wider than $2.5 \mathrm{~mm}$ seem to dysregulate cell death and increase anti-apoptotic bcl-2 protein activity (16), which increases the likelihood of pathological changes arising in the follicle. In this case, extraction could be considered. On the other hand, radiographies do not seem to be an appropriate tool for diagnosing pathological changes and biopsy is recommended (17).

Pericoronitis was indicated as a potential complication by $21 \%$ of the clinicians. However, many indications concerned fully impacted molars, which are not at risk of pericoronaritis unless it is assumed that eruption can still occur. In fact, few $3 \mathrm{Ms}$ remain static and their position changes over time, although this does not necessarily imply eruption (18).

There are still clinicians who support $3 \mathrm{M}$ extraction to prevent late anterior-inferior crowding (19). However, most of the studies published in the last few years have failed to find any association between the eruption of $3 \mathrm{M}$ and crowding of the anterior teeth (20).

The current literature suggests a low prevalence of second molar (2M) external resorption (0.3 to $7 \%$ ), although this percentage can be 4 times higher if, instead of analysing panoramic radiographies, Cone Beam Computed Tomographies (CBCT) are used (21). In the present study, $2 \mathrm{M}$ resorption was selected by more than $11 \%$ of the clinicians as an indication for removing the 3Ms.

The percentage of $3 \mathrm{Ms}$ extracted due to caries on the distal side of $2 \mathrm{M}$ in young patients seems to be very low $(2-5 \%)$. However, in older patients the proportion increases to up to $30 \%$ (22). In the present study, $13 \%$ of the respondents though that the risk of caries in the $2 \mathrm{M}$ 
was an indication for extraction. Almost $2 / 3$ of professionals cited $3 \mathrm{Ms}$ in a horizontal position and classified as Pell \& Gregory IIIA as high-risk cases. Indeed, the probability of developing caries in the distal aspect of the $2 \mathrm{M}$ increases when the angulation between the $3 \mathrm{M}$ and the $2 \mathrm{M}$ is between $43^{\circ}$ and $71^{\circ}(23)$, or if the distance between the cement-enamel junction of the two teeth is between 3 and $10 \mathrm{~mm}$ (24). Several authors have also stressed the importance of age in the development of this complication (27). In fact, according to Kang et al. (23) patients older than 27 have double the risk of caries in the second molar. This reinforces the idea that poorly positioned 3Ms carry a higher caries risk and that it increases with age because of a cumulative effect (24).

Regarding the periodontal health of $2 \mathrm{Ms}, 10.2 \%$ of clinicians believed that $3 \mathrm{M}$ extraction was beneficial, against $1.6 \%$ who found that surgery would only make it worse. Both opinions are supported by clinical evidence (25).

In the present study, $57.9 \%$ of clinicians chose not to remove asymptomatic $3 \mathrm{Ms}$. The main reason was that extraction did not seem necessary, the tooth was still functional or no complications were foreseeable in the short or medium term. The risk of inferior alveolar nerve injury was the second reason given against extraction. Although the literature shows a low incidence of nerve injuries, ranging from $0.4 \%$ to $8 \%, 25 \%$ of cases with nerve injury have irreversible symptoms (26). The Spanish clinicians were more concerned about this complication, probably because they were more familiar with these injuries and the associated risk factors (9).

The risk of mandible fracture and the fact that surgery was too aggressive were also referred to as contraindications for the extraction of 3Ms. However, studies show that fracture is an extremely rare complication and is more common in older patients with fully impacted 3Ms in specific positions (II-III C) (27).

Notwithstanding the methodological constraints of this study, it may be concluded that years of professional experience were negatively correlated with the perceived difficulty of $3 \mathrm{M}$ extraction. In general, surprisingly, dentists in both countries did not have a conservative attitude, but Spanish dentists, who had more oral surgery training, recommend fewer extractions of asymptomatic 3Ms. The risk of pericoronaritis and distal caries in the $2 \mathrm{M}$ were the main reasons for an indication to extract, while the risk of alveolar nerve injury and the aggressiveness of the surgery were the main contraindications.

\section{References}

1. Zou D, Zhao J, Ding W, Xia L, Jang X, Huang Y. Wisdom teeth: Mankind's future third vice-teeth? Medical Hypotheses. 2010;74:52-5.

2. Juodzbalys G, Daugela P. Mandibular third molar impaction: Review of literature and a proposal of a classification. J Oral Maxillofac Res. 2013;4:e1.
3. Boughner JC. Maintaining perspective on third molar extraction. J Can Dent Assoc. 2013;79:106-7.

4. McArdle L, Renton T. The effects of NICE guidelines on the management of third molar teeth. Br Dent J. 2012;213:E8.

5. Mansoor J, Jowett A, Coulthard P. NICE or not so NICE? Br Dent J. 2013;215:209-12.

6. Liedholm R, Knutsson K, Lysell L, Rohlin M, Rohlins M. Mandibular third molars: oral surgeons'assessment of the indications for removal. Br J Oral Maxillofac Surg. 1999;37:440-3.

7. Zadik Y, Levin L. Decision making of Israeli, East European and South American Dental School Graduates in third molar surgery: Is there a difference? J Oral Maxillofac Surg. 2007;65:658-62.

8. Singh H, Lee K, Ayoub AF. Management of asymptomatic impacted wisdom teeth: A multicentre comparison. Br J Oral Maxillofac Surg. 1996;34:389-93.

9. Knutsson K, Lysell L, Rohlin M. Dentists` decisions on prophylactic removal of mandibular third molars: A 10-year follow-up study. Community Dent Oral Epidemiol. 2001;29:308-14.

10. Liedholm R, Knutsson K, Lysell L, Rohlin M, Brickley M, Shepherd JP. Comparison of decisions regarding prophylactic removal of mandibular third molars in Sweden and Wales. Br Dent J. 2001;190:198-202.

11. Obimakinde OS, Okoje VN, Ljarogbe OA, Obimakinde AM. Role of patients'demographic characteristics and spatial orientation in predicting operative difficulty of impacted mandibular third molar. Ann Med Health Sci Res. 2013;3:81-4.

12. Tjalma WAA, Degueldre M, van Herendael B, Herde KD, Weyers S. Postgraduate cadaver surgery: An educational course which aims at improving surgical skills. Facts Views Vis Obgyn. 2013;5:61-5.

13. Berrocal MI, González JM, Rodríguez MD. Social demand in ambulatory oral surgery. Experience in the Master of Oral Surgery of Madrid Complutense University (Spain). Med oral Patol Oral Cir Bucal. 2008;13:39-42.

14. Sisk AL, Martello WB, Shelton DW, Gioia ED. Complications following removal of impacted third molars: the role of the experience of the surgeon. J Oral Maxillofac Surg. 1986;44:855-9.

15. Stathopoulos P, Mezitis M, Titsinides S, Stylogianni E. Cysts and tumors associated with impacted third molars: Is prophylactic removal justified? J Oral Maxillofac Surg. 2011;69:405-8.

16. Razavi SM, Hasheminia D, Mehdizade M, Movahedian B, Keshani F. The relation of pericoronal third molar follicle dimension and bcl-2/ki-67 expression: Na immunohistochemical study. Dent Res J. 2012;9:26-31.

17. Tegginamani AS, Prasad R. Histopathologic evaluation of folicular tissues associated with impacted lower third molars. J Oral Maxillofac Pathol. 2013;17:41-4.

18. Phillips C, White RP. How predictable is the position of third molars over time? J Oral Maxillofac Surg. 2012;70:11-4.

19. Lindauer SJ, Laskin DM, Tufekçi E, Taylor RS, Cushing BJ, Best AM. Orthodontists's and surgeons'opinions on the role of third molars as a cause of dental crowding. Am J Orthod Dentofacial Orthop. 2007;132:43-8.

20. Karasawa LH, Rossi AC, Groppo F, Prado FB, Caria P. Crosssectional study of correlation between mandibular incisor crowding and third molars in young Brazilians. Med Oral Patol Oral Cir Bucal. 2013;18:505-9.

21. Oenning A, Mello S, Groppo F, Haiter-Neto F. Mesial inclination of impacted third molars and its propensity to stimulate external root resorption in second molars - A cone-beam computed tomographic evaluation. J Oral Maxillofac Surg. 2015;73:379-86.

22. McArdle LW, McDonald F, Jones J. Distal cervical caries in the mandibular second molar: An indication for the prophylactic removal of third molar teeth? Update. Br J Oral Maxillofac Surg. 2014;52:185-9.

23. Kang F, Huang C, Kumar M, Jiang B. Effect of eruption status of the mandibular third molar on distal caries in the adjacent second molar. J Oral Maxillofac Surg. 2016;74:1-9.

24. Chang SW, Shin SY, Kum KY, Hong J. Correlation study between distal caries in the mandibular second molar and the eruption 
status of the mandibular third molar in the Korean population. Oral Surg Oral Med Oral Pathol Oral Radiol Endod. 2009;108:838-43.

25. Richardson DT, Dotson TB. Risk of periodontal defects after third molar surgery: an exercise in evidence-based clinical decision making. Oral Surg Oral Med Oral Pathol Oral Radiol Endod. 2005;100:133-7.

26. Bhat $P$, Cariappa KM. Inferior alveolar nerve deficits and recovery following surgical removal of impacted mandibular third molars. J Maxillofac Oral Surg. 2015;11:304-8.

27. Cutilli T, Bourelaki T, Scarsella S, Di Fabio D, Pontecorvi E, Cargini P, et al. Pathological (late) fractures of the mandibular angle after lower third molar removal: a case series. J Med Case Rep. 2013;7:121.

Conflict of Interest

There are no potential conflicts of interest. 